\title{
Багаторічна динаміка змін клімату та водного режиму Південного Буга в зоні впливу південноукраїнського енергокомплексу
}

\author{
О.О. Жолуденко ${ }^{1}$, Р.Я. Бєлєвцев ${ }^{2}$, С.М. Чумаченко ${ }^{3}$, В.А. Дерман ${ }^{4}$, \\ К.Г. Лисиченко ${ }^{5}$, І.В. Струнін ${ }^{6}$, М.А. Бугера ${ }^{7}$, М.М. Кірієнко ${ }^{8}$ \\ 1,2,5 ДУ «Інститут геохімії навколишнього середовища» (м. Київ, Україна) \\ 3, 4,6 Національний університет харчових технологій (м. Київ, Україна) \\ 7 Національний авіаційний університет (м. Харків, Украӥна) \\ 8 Харківський національний технічний університет сільського господарства \\ імені Петра Василенка (м. Харків, Україна) \\ email:1 ozholud@gmail.com, 2 IGNSBBielievtsev@nas.gov.ua, \\ ${ }_{3}^{3}$ sergiy23.chumachenko@gmail.com,4vderman@ukr.net,5 lysychenkoKG@ukr.net, \\ 6 igor.strunin@gmail.com, 7 margobuhera@gmail.com
}

ORCID: 3 0000-0002-8894-4262

\begin{abstract}
У статті проводиться аналіз багаторічної мінливості кліматичних фракторів та водного режиму в межах зони впливу Південноукраїнського енергокомплексу. Для аналізу були використані ряди середньорічних, максимальних і мінімальних витрат води тривалістю до 2017 р. по водпостам Первомайськ (вище ПУЕК) та Олександрівка (нижче ПУЕК). Основні метеорологічні характеристики взяті по метеостанціям Первомайськ та Вознесенськ, оскільки вони розташовані найближче до зони впливу ПУЕК (вище та нижче). Для порівняння та кореляції даних з іншими періодами часу використано ряди метеорологічних показників за весь період спостережень, що проводяться з 1886 р.

Відмічається, що останні декілька десятиліть характеризуються значними темпами потепління, як в цілому по території України, так і в регіоні розташування ПУЕК. На фроні загального підвищення кількості опадів в холодний період року і взагалі річної суми атмосферних опадів, проявилася тенденція досить значного зменшення кількості атмосферних опадів в липні-серпні, причому це зменшення супроводжується істотним підвищенням температури повітря на $5 \pm 2^{\circ} \mathrm{C}$.

Такі регіональні зміни клімату, в певній мірі, можуть стати причиною зменшення водності водойм, через збільшення випаровування при підвищення приземної температури та зменшенні кількості атмосферних опадів, особливо у верхів'ї та в середній частині басейну, а незначне підвищення кількості опадів в нижній частині басейну їх не компенсують (стік в цій частині басейну складає лише 17,5 \% від річного стоку всієї річки).

Формування водного режиму річки Південний Буг у районі розміщення ПУЕК, в останні десятиріччя відбувається на фоні позитивної фази коливань середньорічних температур повітря і негативної фази коливань опадів зимового сезону. Це призвело до суттєвого зменшення середньорічних витрат води р. Південний Буг на досліджувані території (по в/п Первомайськ на 20\%, а по в/п Олександрівка - 30\%).

У стоці річки багатоводний період, який розпочався з кінця 60-х років минулого століття, 3 2007 року змінився маловодним циклом. Сезонний перерозподіл стоку річки з даної території став менш вираженим протягом року. Істотно зменшився сток у весняний період, і збільшився в літній, осінній та зимовий.
\end{abstract}

Ключові слова: річка Південний Буг, Південноукраїнський енергокомплеку (ПУЕК), водпост, метеостаниія, Первомайськ, Олександрівка, клімат, водний режим, сток, Ташлицька гідроакумулююча електростація (ТГАЕС), середньорічна температура повітря, сума атмосфрерних опадів, середньорічні витрати води, різницеві інтегральні криві.

Постановка проблеми. Пріорітетним завданням гідрології на сучасному етапі розвитку суспільства є вивчення впливу діяльності людини на водні ресурси та водний баланс.

Продовж останніх років зацікавленість до оцінки і прогнозу кількісних змін водних ресурсів зростає у зв'язку із змінами кліматичних характеристик (температури повітря, опадів), що реаль- но спостерігаються 3 кінця минулого століття. 3 розвитком промисловості, людство стало спалювати все більше і більше викопних палив (нафта, газ, вугілля), таким чином збільшуючи концентрацію парникових газів в атмосфрері. Більше парникових газів - більше тепла затримується біля поверхні Землі. Антропогенні зміни кліматичних характеристик можуть бути настільки значними [1], 
що призведуть до суттєвих перетворень гідрологічного циклу, кількості водних ресурсів, їх розподілу в часі і по території. Перетворення екстремальних характеристик річкового стоку і їх мінливість не можна не враховувати при розробці довгострокових планів комплексного використання і охорони водних ресурсів, при проектуванні довготривалих водогосподарських заходів.

Аналіз попередніх наукових досліджень. B.І. Вишневський та О.О. Косовець [2] вказують на певні зміни в сучасному стані річок та гідрологічних характеристиках стоку річок України. Відзначається тенденція до збільшення стоку річок у маловодні роки, зростання меженного стоку та зменшення максимальних витрат в період повеней. На думку авторів, цьому сприяло зміна клімату на території України (збільшення температури повітря в зимовий період, зниження висоти снігового покриву, зменшення швидкості вітру). Це стосується як зарегульованих, так і незарегульованих річок. Виняток із загального списку складають річки Українських Карпат (Тиса, Дністер), на яких відбувається збільшення максимального стоку води [2]. Тенденція до збільшення витрат під час паводків може бути пояснена, 3 точки зору авторів, кліматичними змінами, зокрема, зменшенням витрат води на випаровування і наслідками вирубки лісу.

Матеріали та методи дослідження. Південноукраїнський енергетичний комплекс (ПУЕК) складають: Южноукраїнська атомна електростанція (ЮУАЕС), Ташлицька гідроакумулююча електростація (ТГАЕС), Олександрівська гідроелектростанція (ОГЕС) та Олександрівське водосховище (ОВ). ПУЕК - єдине в Україні унікальне підприємство, побудоване за принципом комплексного використання ядерної енергії, маневрених гідроакумулюючих потужностей та водних ресурсів.

В адміністративному відношенні ЮУАЕС, ТГАЕС і ОГЕС з Олександрівським водосховищем розташовані у Миколаївській області на території Арбузинського, Доманівського і Вознесенського районів (рис.1).

Призначення ЮУАЕС - виробництво електроенергії для постачання споживачів південних регіонів України (з населенням більше 5 млн. осіб) Миколаївської, Одеської, Херсонської областей. На сьогодні об'єктивною реальністює те, що ЮУАЕС постачає для України $10 \%$ електроенергії, а для Миколаївської, Одеської і Херсонської областей - $98 \%$.

У зв'язку із змінами клімату, що особливо відчутно проявляються останніми десятиліттями [3], i, зокрема, у зменшенні водності басейну Південного Бугу, ЮУАЕС відчуває дефіцит води, що може в певні періоди обмежувати ії̈ планову потужність.

Метою цієї роботи є дослідження багаторічної мінливості водного режиму р.Південний Буг в зоні впливу Південноукраїнського енергокомплексу (середньо-нижня частина басейну Південного Буга), у зв'язку зі змінами клімату.

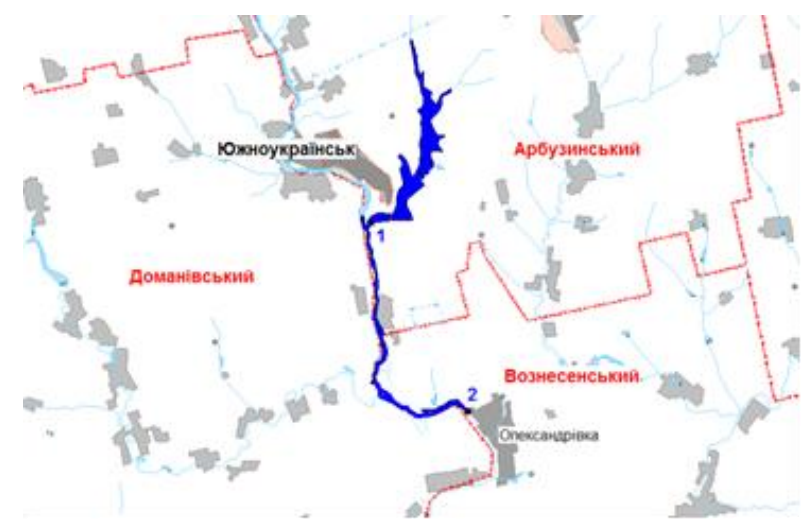

Рис. 1. - Карта адміністративних районів, у межах яких розташований ПУЕК

1 - гребля ТГАЕС; 2 - гребля ОГЕС

У даній роботі використовувалися ряди середньорічних, максимальних і мінімальних витрат води тривалістю до 2017 р. по водпостам Первомайськ (вище ПУЕК) та Олександрівка (нижче ПУЕК). Основні метеорологічні характеристики взяті по метеостанціям Первомайськ та Вознесенськ, оскільки вони розташовані найближче до зони впливу ПУЕК (вище та нижче). Для порівняння та кореляції даних з іншими періодами часу використано ряди метеорологічних показників за весь період спостережень, що проводяться з 1886 р.

Всі наявні дані оброблялися за відомими стандартними методиками статистичного аналізу метеорологічної інформації, викладеним в підручниках і іншій літературі.

Виклад основного матеріалу досліджень. Район дослідження розміщено в південнозахідній частині Придніпровської височини і характеризується типовим долино-яружним рельєфом з рівнинним слабохвилястим межиріччям i глибоко врізаними долинами рік. Сучасний рельєф території обумовлений геологічною будовою, неотектонічними рухами, ерозійною діяльністю рік і кліматичними особливостями. Тектонічне підняття території, що продовжується дотепер, спричинює домінування процесів ерозії і змиву над процесами акумуляції, що відображено в глибокому ерозійному урізі долин рік, майже повній відсутності алювіальних відкладів в їх руслах і у слабкому розвитку акумулятивних терас за рахунок активних процесів ерозії.

Мінімальні абсолютні відмітки земної поверхні (+0,9 м; 6,85 і 35,0 м) зафіксовано у русловій частині долини Південного Бугу відповідно на ділянках Олександрівського перетину (місце розташування греблі ГЕС) і вище о-ва Гард, 
максимальні відмітки характерні для вододілів (135-150 м). Амплітуда коливань висотних відміток сягає 130-149 м. Такий висотний перепад на відносно короткій ділянці є сприятливим чинником для акумулювання гідроенергії та ії̈ використання в електроенергетичних цілях.

У межах району чітко виділяється плато з пологими схилами, розсічене долинами Південного Бугу, Мигіївського Ташлика, Корабельної, Бакшали на окремі ділянки, які, у свою чергу, розчленовані мережею балок і ярів, найбільш великі 3 яких впадають безпосередньо у долину Південного Бугу. Таких балок на лівобережжі нараховується 13, на правобережжі - 16.

Долина Південного Бугу часто змінює ширину та ухил уздовж потоку. На окремих ділянках ріка Південний Буг прорізує кристалічні породи, тут її долина звужується та набуває вигляду каньйону зі скелястими й крутими схилами. Там, де ріка прорізує товщу осадових порід, долина розширюється, в цих місцях її схили пологі. Поздовжний профріль долини не вироблений, в руслі часто трапляються пороги і перекати.

Основною ґрунтотвірною породою на території зони впливу Південноукраїнського енергокомплексу є леси. 3 півночі на південь вони вкривають увесь простір міжріччя.

Долини рік, вкриті алювіальними відкладами, представлені жовтувато-бурими чи сірувато-жовтими карбонатними суглинками й супісками, зумовлюють утворення лукових, луково-болотних і болотних ґрунтів.

На вододільних рівнинних ділянках, їх схилах сформувались переважно родючі чорноземні ґрунти на лесах і лесоподібних суглинках четвертинного періоду. На шлейфах схилів і в балках на делювіальних лесових породах утворились чорноземи намиті та луково-чорноземні ґрунти.

Кліматичні умови в регіоні розташування ПУЕК $є$ помірно-континентальними, з недостатнім режимом зволоженням, що характерно для степової зони (арідним літом, м'якою малосніжною зимою та частою повторюваністю посушливих явищ) [4].

Середньорічна приземна температура повітря в середньо-нижній частині басейну Південного Бугу коливається в межах 8-10 оС. Так, на метеостанціях, які розташовані в цьому регіоні Первомайськ та Вознесенськ метеорологічна норма температури за період 1886-2017 рр. становить 8,6 та 9,2 оС, а річна сума атмосферних опадів, відповідно, 521 та 535 мм (в окремі роки мінімальна сума атмосферних опадів складала 301 мм, а максимальна 966 мм за рік).

Вегетаційний період в нижній частині басейну Південного Бугу триває в середньому 225 4 дні [4].

Відносна середньорічна вологість повітря в регіоні становить 75-70\%, в холодний період року

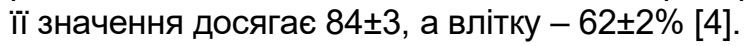

Сумарне випаровування в середньо-нижній частині басейну р. Південний Буг має сезонну залежність: взимку біля до 30-40 мм, влітку до 200300 мм, навесні до 125-160 мм, а восени до 8095 мм. В пониззях Південного Бугу середня кількість днів з туманом протягом року біля 30-39 дні, найчастіше тумани в холодний період року [4,5].

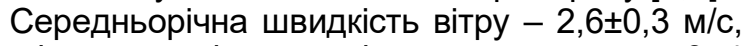
більші швидкості спостерігається взимку до 3-4 м/с, а влітку в середньому до 2 м/с., причому сильні вітри зі швидкістю $\geq 15 \mathrm{~m} / \mathrm{c}$ в середньому спостерігаються 30-35 днів, а в окремі роки до 65 днів за рік, а повторюваність ураганних вітрів із швидкістю $\geq 30$ м/с зафріксовано 1 раз за 25 років [4]. Протягом року переважними напрямками вітру $€$ південно-західний і південно-східний до 16-17\%.

Зазначимо, що значення метеопараметрів можуть дещо змінюватись в залежності від вибраного періоду, через наявність квазіперіодичних коливань та під впливом сучасних змін клімату[3].

На території України в XX ст. під впливом глобальних процесів відбулися певні зміни клімату (підвищення приземної температури на 0,6 0,1 оC/100 років) і останні декілька десятків років потепління клімату стало більш інтенсивним із збільшенням повторюваності кліматичних аномалій в різні пори року $[3,6,7]$.

Якщо розглядати основні кліматичні чинники досліджуваної території по метеостанціях Первомайськ та Вознесенськ тільки за післявоєнний період з 1945-2018 рр., то простежується тенденція, як до збільшення температур повітря, так і збільшення опадів. Так, значення коефіцієнтів лінійних трендів ходу середньорічної температури повітря (рис.2) за цей період по метеостанціям Первомайськ (а) та Вознесенськ (б) становлять, відповідно, 2,26 та 2,07 оС/100 років (при середній багаторічній приземній температурі за період $9,1 \pm 1,0$ та 10,0 1,0 оС, відповідно).

На фроні загального підвищення температури розгортаються квазіперіодичні коливання, які приводять до відносного похолодання, наприклад, 60-80-і роки XX ст. та інтенсифікують потепління 90-і роки XX ст. та початок XXI ст. [3,6].

Відмітимо, що останні декілька десятиліть характеризуються значними темпами потепління, як в цілому по території України, так і на південному заході країни (регіон розміщення ПУЕК) [10].

Потепління клімату в глобальних і регіональних масштабах стали причиною просторово-часового перерозподілу кількості атмосферних опадів на території України. Так, $X X$ ст. в південно-західних, південних та південно-східних регіонах України встановлено підвищення річної кількості атмосферних опадів на $10 \pm 5 \%[3,6]$.

За даними спостережень на метеостанціях Первомайськ та Вознесенськ за період 19452017 рр. річна сума атмосферних опадів стано-

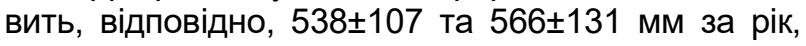
значення коефіцієнтів лінійних трендів становлять, відповідно, 21,6 та 18,5 мм/100 років (рис.3). 


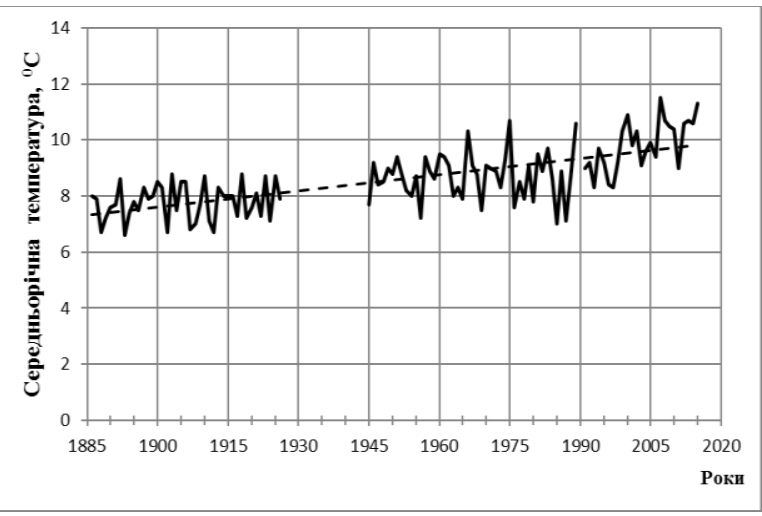

A

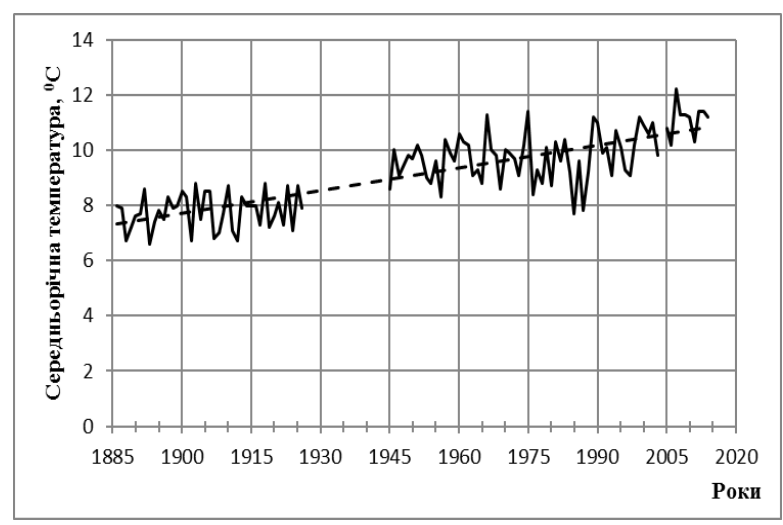

Б

Рис. 2. Багаторічні зміни середньорічної температури повітря та лінії їх тренду по метеостанціям Первомайськ (А) та Вознесенськ (Б).

Таким чином, за останні 70 років в даному регіоні річна сума атмосфрерних опадів виросла на $5 \pm 2 \%$

Як засвідчує аналіз гідрологічних даних 3 1914 по 2017 р. по найбільш довгому ряду стоку р. Південний Буг - смт Олександрівка, незважаючи на значну зарегульованість (близько 200 водосховищ і 6,9 тис. ставків сумарним об'ємом 1,5 км$\left.^{3}\right)$ і широке використання водних ресурсів для загальногосподарських потреб, середньорічні витрати Південного Бугу в районі гирла ріки за період з 1914 по 1950 р. становили 87,0 м $3 /$. Після створення більшості водосховищ і ставків (1951-1980) вони зросли до 93 м $3 / c$, після спорудження водойми-охолоджувача ЮУ AEC і заповнення Олександрівського водосховища до відмітки НПР 14,7 м (1981-2006) істотно не змінились і становлять понад 91 м³/c (рис.4).

Зіставляючи різницеві інтегральні криві температур повітря (рис.5), річних опадів (рис.6) і стоку (рис.7), можна зробити висновок, що коливання річного стоку визначаються, в першу чергу, багаторічної динамікою опадів. Негативна фаза коливань річних опадів супроводжується маловоддям, а волога (позитивна) - багатоводдям

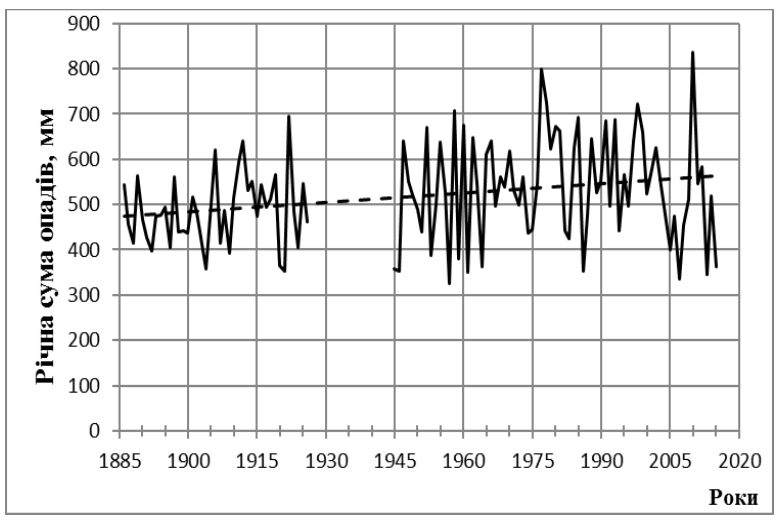

A

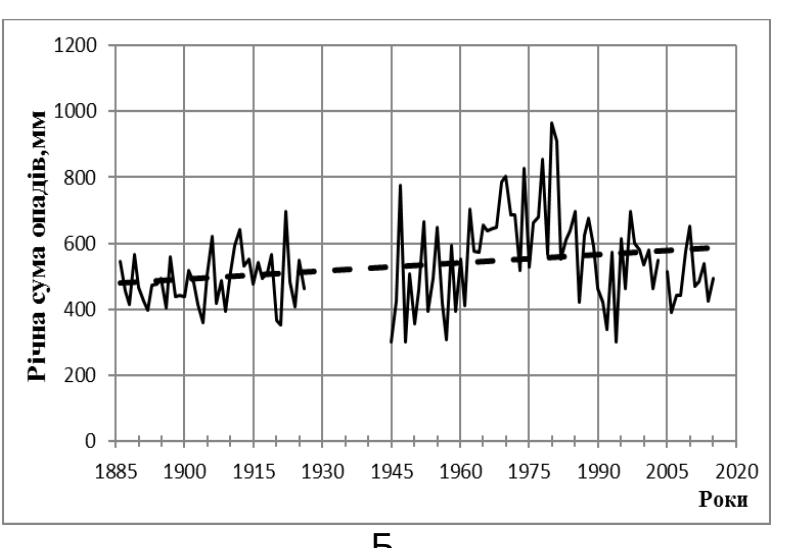

Б

Рис.3. Багаторічні зміни річних сум опадів та лінії їх тренду по метеостанціям Первомайськ (А) та Вознесенськ (Б).

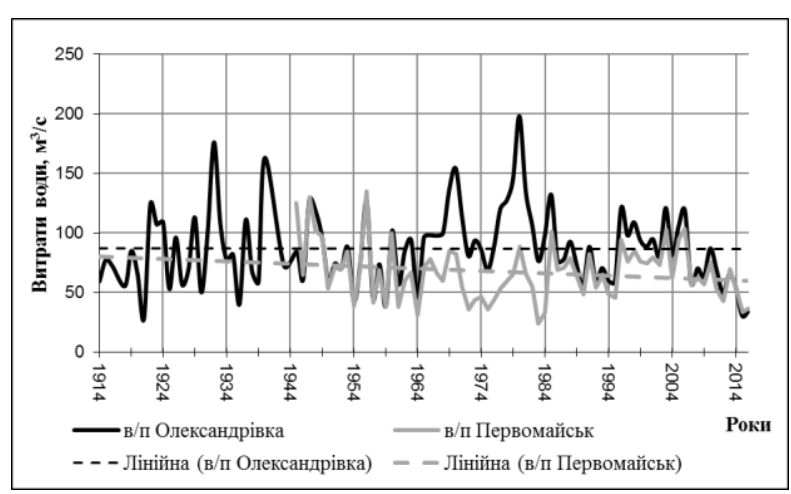

Рис.4. Багаторічні зміни стоку р. Південний Буг та лінії їх тренду на водпостах Первомайськ та Олександрівка

3 сезонних особливостей кліматичних факторів слід зазначити циклічність коливань опадів зимового сезону (грудень-лютий). Так, період до 1995 року відповідає коливанням річних опадів, але на відміну від останніх переходу у вологу фразу (з 1997 р) не відбувається (рис. 8). В умовах сучасних змін клімату проявилися певні тенденції у сезонному ході приземної температури. 


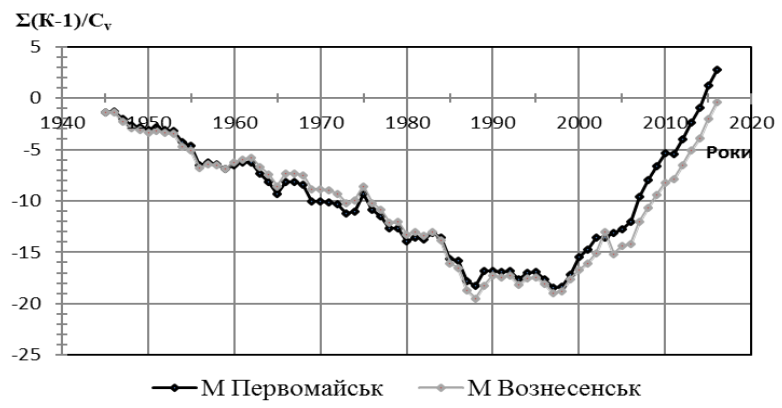

Рис.5. Різницева інтегральна крива середньорічних температур повітря по метеостанціям Первомайськ та Вознесенськ

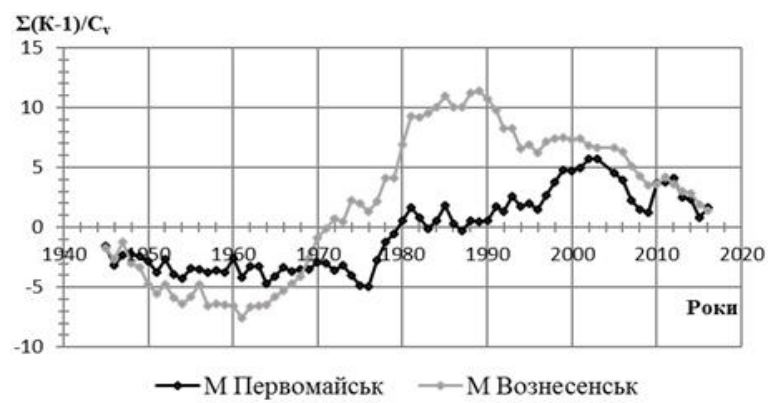

Рис.6. Різницева інтегральна крива річних сум опадів по метеостанціям Первомайськ та Вознесенськ

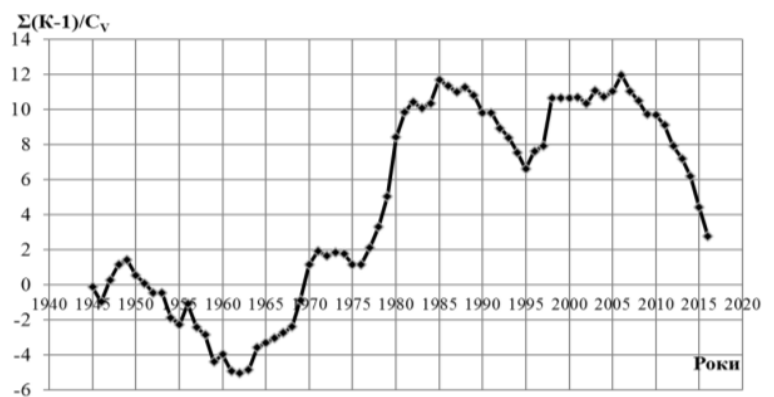

Рис.7. Різницева інтегральна крива стоку

р. Південний Буг - в/п Олександрівка

Так, в XX ст. (для періоду 1945 - 2000 рр.) для метеостанцій Первомайськ та Вознесенськ максимум потепління був характерний для зимових місяців і початку весни (3 - $6^{\circ} \mathrm{C} / 100$ років), а в літні місяці майже не потеплішало, а іноді і навпаки до 1,0 - 1,5 $\mathrm{C} / 100$ років). Але для періоду 1971-2016 рр. на фоні тенденції до потепління в холодний період року проявилася тенденція досить значного потепління в липні-серпні (див. рис. 9). Слід відмітити, що на метеостанції Первомайськ сезонні зміни біль інтенсивні, ніж на метеостанції Вознесенськ (через мікрокліматичні особливості).

Слід відмітити, що таке істотне підвищення температури влітку інтенсифрікує випаровування і призводить, в тому числі, і до зменшення водності водосховищ.

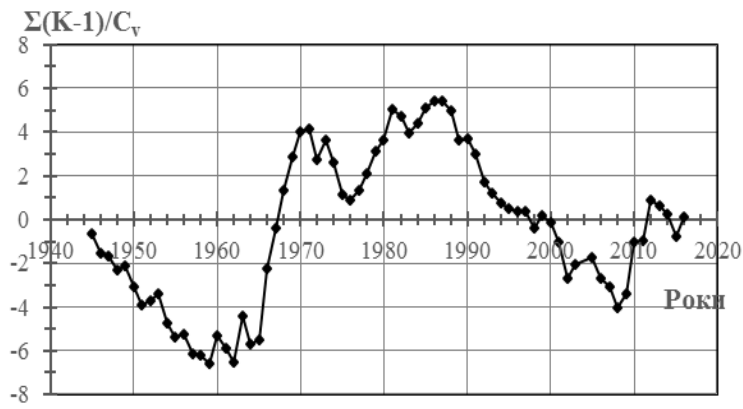

Рис.8. Різницева інтегральна крива сум опадів за зимовий сезон по метеостанції Первомайськ

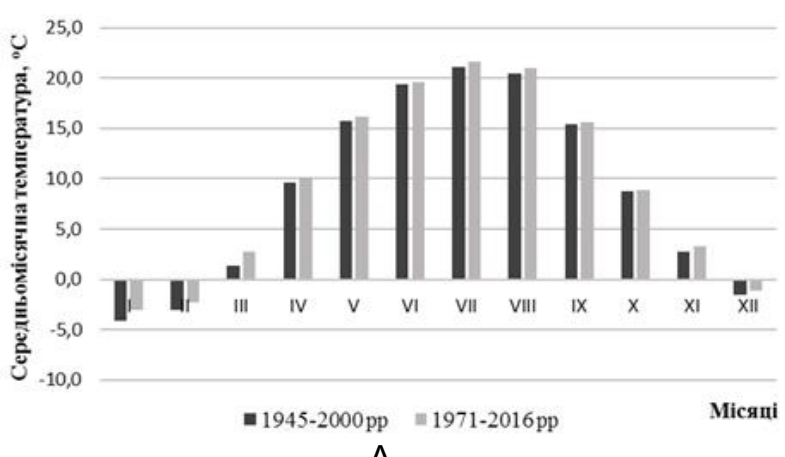

A

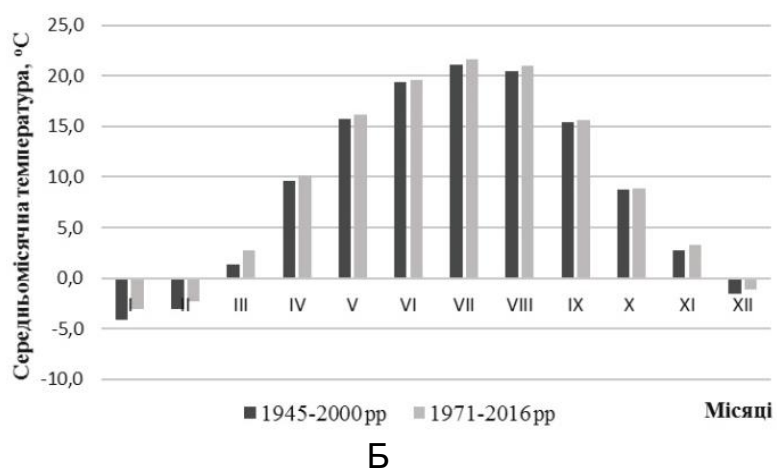

Рис.9. Динаміка ходу середньомісячної температури повітря на метеостанціях Первомайськ

(А) та Вознесенськ (Б) за періоди спостережень 1945-2000 та 1971-2016 рр

Зміни у сезонному ході температурного режиму в XX ст. і на початку XXI ст. призвели до зменшення амплітуди сезонного ходу температури на $-0,5 \pm 1^{\circ} \mathrm{C}$ за 100 років, що $€$ проявом ефекту деконтиненталізації клімату [3,6].

В сезонному розподілі кількості атмосферних опадів в умовах сучасних змін клімату також проявилися певні тенденції. Так, в XX ст. протягом періоду 1945-2000 рр. для метеостанцій Первомайськ та Вознесенськ максимальні зміни були характерні для перехідних сезонів (на фоні загального збільшення річної суми атмосферних опадів до 10 \%) (див.рис. 10) [3,6]. 
Але для періоду 1971 - 2016 рр. (на фоні загального підвищення кількості опадів в холодний період року і взагалі річної суми атмоссрерних опадів) проявилася тенденція досить значного зменшення кількості атмосфрерних опадів в липнісерпні. Причому це зменшення кількості атмоссрерних опадів на $75 \pm 30 \mathrm{~mm} / \mathrm{mic.} \mathrm{в} \mathrm{липні-серпні}$ супроводжується істотним підвищенням температури повітря на $5 \pm 2^{\circ} \mathrm{C}$.

3 рис. 7 видно, що на 1981 р припадає початок наступного гідрологічного циклу, тому весь період спостережень доцільно розбити на два

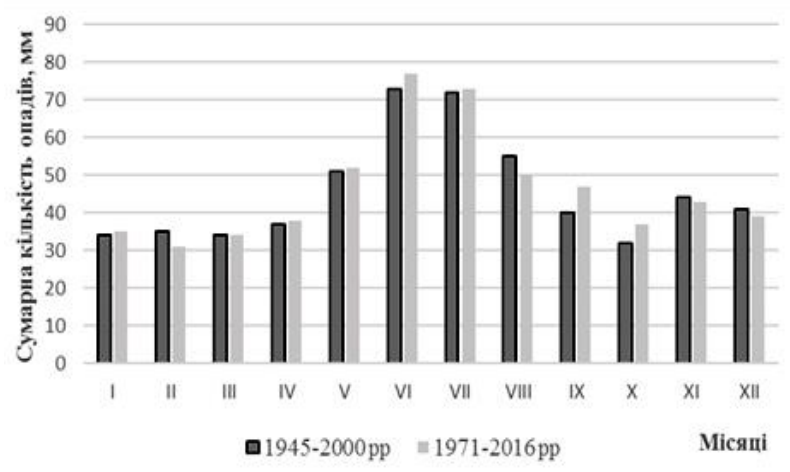

A періоди: від початку спостережень до 1980 р і від 1981 до 2016 року. За цим періодам було визначено внутрішньорічний розподіл стоку, який представлено в табл.1 і графрічно на рис.11.

Як видно з рис. 11 внутрішньорічний розподіл стоку в зоні впливу ПУЕК характеризується певною рівномірністю протягом року. Деяке підвищення витрат на початку осені (серпень-вересень), пояснюється більшими скидами води з водосховища за найнесприятливіших умов формування стоку Південного Бугу в кінці літа-на початку осені.

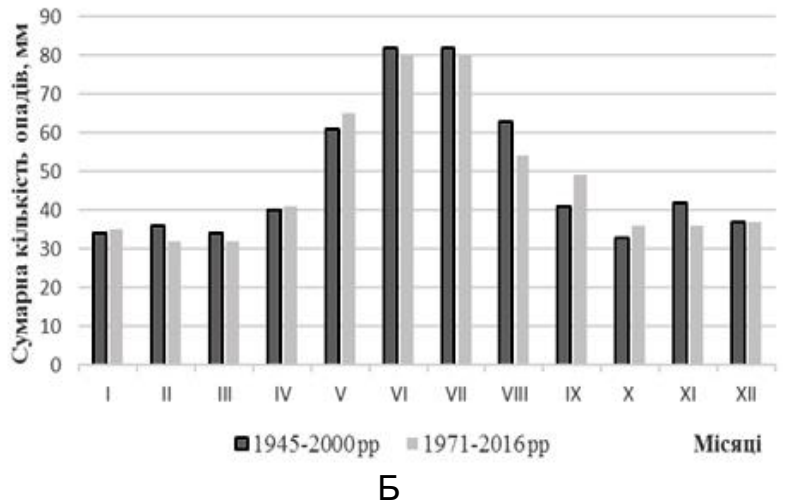

Б

Рис.10. Динаміка ходу річної кількості опадів на метеостанціях Первомайськ (А) та Вознесенськ (Б) за періоди спостережень 1945-2000 та 1971-2016 рр

Таблиця 1. Внутрішньорічний розподіл стоку (частка у році, виражена у відсотках) р.Південний Буг на водпостах Первомайськ і Олександрівка

\begin{tabular}{|c|c|c|c|c|c|c|c|c|c|c|c|c|}
\hline \multirow{2}{*}{ Період } & \multicolumn{12}{|c|}{ Місяці } \\
\hline & 1 & II & III & IV & V & $\mathrm{VI}$ & VII & VIII & IX & $\mathrm{X}$ & $\mathrm{XI}$ & XII \\
\hline в/п Первомайськ & \multicolumn{12}{|c|}{ частка, \% } \\
\hline $1945-1980 p p$. & 6,0 & 11,3 & 28,2 & 17,7 & 4,8 & 4,8 & 4,3 & 4,1 & 4,0 & 4,2 & 5,1 & 5,5 \\
\hline $1981-2016 p p$. & 7,6 & 9,2 & 14,8 & 15,1 & 7,1 & 6,3 & 5,9 & 4,8 & 5,4 & 8,6 & 8,1 & 7,1 \\
\hline в/п Олександрівка & \multicolumn{12}{|c|}{ частка, \% } \\
\hline $1918-1980 p p$. & 5,6 & 8,3 & 23,9 & 20,5 & 6,8 & 5,3 & 5,2 & 4,4 & 4,3 & 4,8 & 5,3 & 5,6 \\
\hline $1981-2016 p p$. & 8,4 & 9,7 & 13,7 & 13,8 & 6,3 & 6,4 & 6,4 & 4,8 & 5,3 & 9,9 & 7,6 & 7,7 \\
\hline
\end{tabular}

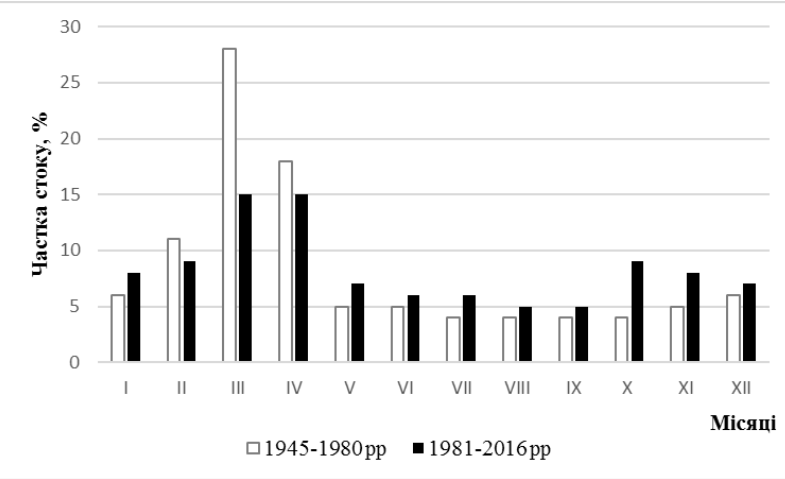

A

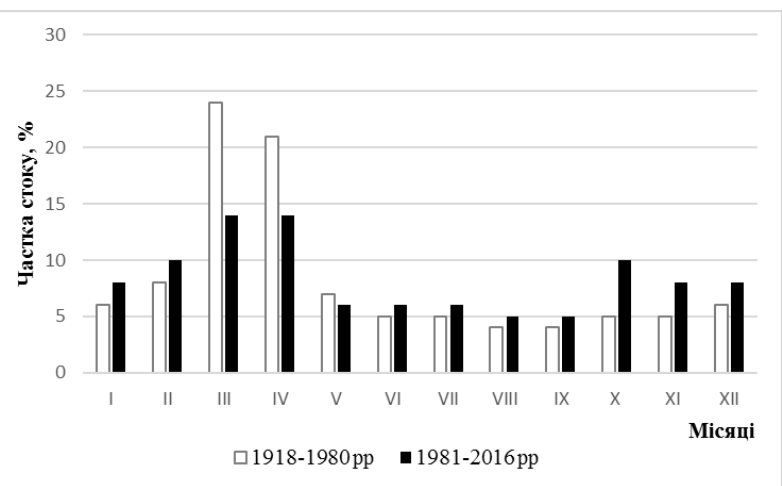

Б

Рис.11. Внутрішньорічний розподіл стоку (частка у році, виражена у відсотках) р.Південний Буг по водпостам Первомайськ (А ) і Олександрівка (Б)

Інженерія природокористування, 2020, №4(18), с. 124 - 132

Engineering of nature management, 2020, \#4(18), p. 124 - 132 
У цілому на фрормування витрат води $\mathrm{p}$. Південний Буг—смт Олександрівка певний вплив має Ташлицьке водосховище наливного типу, що $€$ водоймою-охолоджувачем ЮУ АЕС, та Олександрівське водосховище руслового типу, які експлуатуються ПУ ЕК.

При порівнянні двох згаданих періодів відзначаємо значне вирівнювання стоку річки на розглянутій території. Істотно зменшився сток у весняний період, на водпосту Первомайськ в середньому на $13,7 \%$, а на водпосту Олександрівка - на $17,4 \%$, i збільшився в літній, осінній та зимовий.

Висновки. 3 початку XX ст., за оцінками експертів $\mathrm{OOH}$, збільшення викидів $\mathrm{CO}_{2}$ становило від 0,5 до 5\% на рік. У результаті за останні сто років тільки за рахунок спалювання палива в атмосферу надійшло 400 млрд т вуглекислого газу. Зараз атмосфера містить на 25\% більше вуглекислого газу, ніж було накопичено в ній за останні 160 тис. років [9]. Відзначимо ще одну проблему, яка виявилася «непоміченою» при аналізі посилення парникового ефекту за рахунок викидів в атмосфреру діоксиду вуглецю при спалюванні органічного палива: у реакціях горіння газу або нафтопродуктів утворюється вода, вірніше, розігрітий водяний пар. Підраховано, що викиди водяної пари в атмосферу (61\%), нафтогазовим паливно-енергетичним комплексом світу за кількістю на порядок перевершують викиди діоксиду вуглецю (21\%), адже водяна пара $є$ головним парниковим газом на Землі [8].

Останні декілька десятиліть характеризуються значними темпами потепління, як в цілому по території України, так і в регіоні розміщення ПУЕК. Потепління клімату в глобальних і регіональних масштабах стали причиною просторовочасового перерозподілу кількості атмосферних опадів на території України. Збільшення середньорічних температур повітря за період з 1945 до 2016 року склало 0,5 С, річних опадів - 25-50 мм.

Зміни у сезонному ході температурного режиму в XX ст. і на початку XXI ст. призвели до зменшення амплітуди сезонного ходу температури на $-0,5 \pm 1^{\circ} \mathrm{C}$ за 100 років, що $€$ проявом ефекту деконтиненталізації клімату.

В сезонному розподілі кількості атмосферних опадів протягом періоду 1945-2000 рр. для метеостанцій Первомайськ та Вознесенськ максимальні зміни були характерні для перехідних сезонів (на фоні загального збільшення річної суми атмосорерних опадів до 10 \%). Але для періоду 19712016 рр. (на фоні загального підвищення кількості опадів в холодний період року і взагалі річної суми атмосфрерних опадів) проявилася тенденція досить значного зменшення кількості атмосферних опадів в липні-серпні. Причому це зменшення кількості атмосферних опадів на $15 \pm 30 \mathrm{~mm} / \mathrm{mic}$. в липні-серпні супроводжується істотним підвищенням температури повітря на $5 \pm 2{ }^{\circ} \mathrm{C}$.
Такі регіональні зміни клімату, в певній мірі, можуть стати причиною зменшення водності водойм, через збільшення випаровування при підвищення приземної температури та зменшенні кількості атмосферних опадів, особливо у верхів'ї та в середній частині басейну, а незначне підвищення кількості опадів в нижній частині басейну їх не компенсують (стік в цій частині басейну складає лише 17,5 \% від річного стоку всієї річки).

Формування водного режиму річки Південний Буг у районі розміщення ПУЕК, в останні десятиріччя відбувається на фоні позитивної фрази коливань середньорічних температур повітря і негативної фази коливань опадів зимового сезону. Це призвело до суттєвого зменшення середньорічних витрат води р. Південний Буг на досліджувані території (по в/п Первомайськ на $20 \%$, а по в/п Олександрівка - 30\%).

\section{Література:}

1. Будыко М.И. Эволюция биосферы. - Л.: Гидрометеоиздат, 1984. - 488c.

2. Вишневський В.І., Косовець О.О. Гідрологічні характеристики річок України. - К.: НікаЦентр. - 2003. - 324 c.

3. Бойченко С.Г. Напівемпіричні моделі та сценарії глобальних і регіональних коливань змін клімату. -Київ: Наукова думка, 2008. -310 с.

4. Клімат України: Ліпінський В., Дячук В., Бабіченко В. (ред.). Київ: Вид-во Раєвського, 2003. -344 . c.

5. Кліматичний кадастр України (кліматична норма метеопараметрів за період 1961-1990рр.) // http://www.cgo.kiev.ua/index.php?dv=pos-klimkadastr. (Accessed 13.06.2017)

6. Волощук В.М., Бойченко С.Г. Сценарії можливих змін клімату України в 21 ст. (під впливом глобального антропогенного потепління). Клімат України. -Київ: Вид-во Раєвського, 2003. - С.319-330.

7. Клімат України: у минулому... і майбутньому? /М. І. Кульбіда, М. Б. Барабаш, Л. О. Єлістратова, Т. І. Адаменко, Н. П. Гребенюк, О. Г. Татарчук, Т. В. Корж /За ред. М. І. Кульбіди, М. Б. Барабаш : Моногр. - К.: Сталь, 2009. - 234 с.

8. Бєлєвцєв Р.Я., Бойченко С.Г.,Співак С.Д. Термодинаміка газового обміну у навколишньому середовищі. -Київ: Наукова думка, 2007. -248 с.

9. Парниковий ефект і зміни клімату в Україні: оцінки та наслідки : монографрія / О. А. Апостолов, І. Г. Артеменко, М. Б. Барабаш та ін.; [за ред. В. І. Лялька]. - Київ : Наук. думка, 2015. - 284 с.

10. Boychenko S., Voloshchuk V., Movchan Ya., Serdjuchenko N., Tkachenko V., Tyshchenko O., Savchenko S. Features of climate change on Ukraine: scenarios, consequences for nature and agroecosystems // Proceedings of the National Aviation University. - 2016. - N4. - P.96-113. DOI: 10.18372/2306-1472.69.11061. 


\section{References:}

1. Budyko M., 1984. The evolution of the biosphere, Hydrometeoizdat, Leningrad, p.488

2. Vyshnevskiy V., Kosovets O., 2003. Hydrolo $\operatorname{cical}$ characteristics of rivers of Ukraine, Kyiv, Nika-Center, p. 324

3. Boychenko S., 2008. Semi-empirical models and scenarios of global and regional climate change fluctuations, Nauk. Dumka, Kyiv, p. 310

4. Lipinskiy V., Dyachuk V., Babichenko V. 2003. Climate of Ukraine, Raevskiy Edition, Kyiv. p. 344

5. Climatic cadaster of Ukraine (climatic norm of meteoparameters for the period 1961-1990) // http://www.cgo.kiev.ua/index.php?dv=pos-klim-kadastr. (Accessed 13.06.2017)

6. Voloshchuk V., Boychenko S., 2003. Scenarios of possible climate change in Ukraine in the 21st century. (under the influence of global anthropogenic warming). The climate of Ukraine, Raevskiy Edition, Kyiv. pp.319-330.

7. Kulbida M., Barabash O. Eilistratova L., Adamenko T., Grebenyuk N., Tatarchuk O., Korzh T., 2009. The climate of Ukraine: in the past ... and in the future? /, Stal, Kyiv. p. 234

8. Belevtsev R., Boychenko S., Spivak S. 2007. Thermodynamics of gas exchange in the environment, Nauk. Dumka, Kyiv, p. 248

9. Apostolov O., Artemenko I., Barabash M. and others. 2015. Greenhouse effect and climate change in Ukraine: assessment and consequences, monograph, Nauk. Dumka, Kyiv, p. 284

10. Boychenko S., Voloshchuk V., Movchan Ya., Serdjuchenko N., Tkachenko V., Tyshchenko O., Savchenko S. 2016. Features of climate change on Ukraine: scenarios, consequences for nature and agroecosystems. Proceedings of the National Aviation University. (4), pp.96-113. DOI: 10.18372/2306-1472.69.11061.

\title{
Аннотация
}

\section{Многолетняя динамика изменения климата и водного режима Южного Буга в зоне влияния южноукраинского энергокомплекса}

\author{
О.А. Жолуденко, Р.Я. Белевцев, С.Н. Чумаченко, В.А. Дерман, \\ К.Г. Лисиченко, И.В. Струнін, М.А. Бугера, Н.М. Кириенко
}

В статье проводится анализ многолетней изменчивости климатических факторов и водного режима в пределах зоны влияния Южно энергокомплекса. Для анализа были использованы ряды среднегодовых, максимальных и минимальных расходов воды продолжительностью до 2017 г.. По водпосту Первомайск (выше ЮУЭК) и Александровка (ниже ЮУЭК). Основные метеорологические характеристики взятые по метеостанциям Первомайск и Вознесенск, поскольку они расположены ближе к зоне влияния ЮУЭК (выше и ниже). Для сравнения и корреляции данных с другими периодами времени использовано ряды метеорологических показателей за весь период наблюдений, проводимых с 1886

Отмечается, что последние несколько десятилетий характеризуются значительными темпами потепление, как в целом по территории Украины, так и в регионе расположения ЮУЭК. На фоне общего повышения количества осадков в холодный период года и вообще годовой суммы осадков, проявилась тенденция довольно значительного уменьшения количества атмосферных осадков в июле-августе, причем это уменьшение сопровождается существенным повышением температуры воздуха на $5 \pm 20 \mathrm{C}$. В стоке реки многоводный период, который начался с конца 60-х годов прошлого века, с 2007 года изменился маловодные циклом. Сезонный перераспределение стока реки с данной территории стал менее выраженным в течение года. Существенно уменьшился сток в весенний период, и увеличился в летний, осенний и зимний

Ключевые слова: река Южный Буг, Южно енергокомплеку (ЮУЭК), водпосту, метеостанция, Первомайск, Александровка, климат, водный режим, сток, Ташлыкская гидроаккумулирующая електростация (ТГАЭС), среднегодовая температура воздуха, сумма осадков, среднегодовые расходы воды, разностные интегральные кривые

\section{Abstract \\ Long-term changes of climatic factors and water regime in the zone of impact of the south-ukrainian energy complex

\author{
O.O. Zholudenko, R.Y. Belevtsev, S.M. Chumachenko, V.A. Derman, \\ K.G. Lisichenko, I.V. Strunin, M.A. Bugera, M.M. Kiriienko
}

In the article long-term changes of climatic factors and water regime in the zone of impact of the SouthUkrainian Energy Complex (SUEC) are analyzed. The length of the series consisting of the average annual, maximum and minimum average year of water consumption until 2017 from Pervomaisk water (under SUEC) post and Oleksandrivka water post (below SUEC) are used. The main meteorological characteristics from

ISSN 2311-1828

http://enm.khntusg.com.ua
Інженерія природокористування, 2020, №4(18), с. 124 - 132

Engineering of nature management, 2020,\#4(18), p. 124 - 132 
Pervomaisk and Voznesensk meteorological stations, because they are situated close to the zone of impact of the SUEC (under and below), were taken.

The length of the series for meteorological characteristics of the entire period of monitoring since 1886, for the data comparison and correlation, were carried out.

Last several decades as in the whole territory of Ukraine and in the zone of impact of SUEC the significant warming processes are observed. Due to general increasing of precipitation amount in cold period of the year and in general the annual amount of precipitation, the tendency for a significant decrease of precipitation amount in July-August was observed. Such decreasing is accompanied by the significant increase of the air temperature at $5 \pm 2{ }^{\circ} \mathrm{C}$. In the flow of the river the rich-water period, which began in the late 60 's of the last century, has changed to water-poor cycle since the 2007. Seasonal redistribution of river flow from this territory became less expressed during the year. The drainage significantly decreased in the spring period, and increased in summer, autumn and winter periods.

Keywords: the Southern Bug River, South-Ukrainian Nuclear Power Plant (SUNPP), water post, meteorological stations, Pervomaysk, Oleksandrivka, climate, water regime, runoff, Tashlytska Storage Plant (Tashlytska SP), average annual air temperature, amount of precipitation, average annual water consumption, difference integral curves.

\section{Бібліографічне посилання/ Bibliography citation: Harvard}

Zholudenko, O. O. et al. (2020) 'Long-term changes of climatic factors and water regime in the zone of impact of the south-ukrainian energy complex', Engineering of nature management, (4(18), pp. 124 - 132.

Подано до редакції / Received: 02.11.2020 